\title{
Teknik Self-Management sebagai Upaya Mereduksi Gaya Hidup Hedonis Siswa SMA
}

\author{
Jihan Zul Fahmi ${ }^{1}$, M. Ramli ${ }^{1}$, Nur Hidayah ${ }^{1}$ \\ ${ }^{1}$ Bimbingan dan Konseling-Universitas Negeri Malang
}

\begin{tabular}{l}
\hline INFO ARTIKEL \\
\hline Riwayat Artikel: \\
Diterima: $01-07-2019$ \\
Disetujui: $23-10-2019$ \\
\hline
\end{tabular}

\section{Kata kunci:}

self management; hedonic lifestyle; high school student; self management; gaya hidup hedonis; siswa SMA

\begin{tabular}{l} 
Alamat Korespondensi: \\
Jihan Zul Fahmi \\
Bimbingan dan Konseling \\
Universitas Negeri Malang \\
Jalan Semarang 5 Malang \\
E-mail: jihanzulfahmi993@ gmail.com \\
\hline
\end{tabular}

\section{ABSTRAK}

Abstract: Hedonic lifestyle is an excessive lifestyle that prioritizes material pleasure and enjoyment. The hedonic lifestyle in high school students is of particular concern. The purpose of this research to find out effectiveness of self-management techniques for reduce the hedonic lifestyle of student of SMAN 8 Malang with twelve student subject. This research used non equivalent control group design, by giving pretest and posttest to each group. The results showed that self-management techniques are effective than modeling techniques.

\begin{abstract}
Abstrak: Gaya hidup hedonis merupakan gaya hidup berlebihan yang mengutamakan kesenangan dan kenikmatan materi. Gaya hidup hedonis yang menjadi perhatian khusus yaitu pada siswa SMA. Tujuan penelitian ini untuk menguji keefektifan teknik selfmanagement untuk mereduksi gaya hidup hedonis siswa SMAN 8 Malang dengan subjek 12 siswa. Penelitian ini menggunakan nonequivalent control group design, dengan memberikan pretest dan posttest pada setiap kelompok. Hasil penelitian menunjukkan bahwa teknik self-management lebih efektif daripada teknik modeling.
\end{abstract}

Pada era globalisasi saat ini, setiap individu dituntut untuk menyesuaikan diri dengan perkembangan yang terjadi. Kebanyakan individu akan mengalami dua fenomena yaitu modernisasi dan globalisasi. Fenomena tersebut terjadi pada sebagian generasi yang ada di Indonesia, terutama pada remaja. Pada era globalisasi, semua individu dipermudah dengan adanya berbagai kemajuan teknologi, khususnya remaja. Menurut Yanti (2016), globalisasi dapat berpengaruh pada remaja zaman sekarang, contohnya dalam hal pemenuhan kebutuhan gaya hidupnya. Salah satu pengaruh globalisasi yaitu perubahan gaya hidup masyarakat. Seiring perkembangan zaman, gaya hidup akan selalu mengalami perubahan, sebagian individu menganggap gaya hidup itu penting karena bisa menunjukkan simbol identitas diri (Safitri, 2012).

Gaya hidup yang ada dalam diri individu, terdiri atas (1) gaya hidup hedonis yang dilakukan individu merupakan suatu tindakan yang bertujuan untuk mencari kesenangan. Individu tersebut lebih cenderung senang pada keramaian kota dan sering nongkrong, tidak suka barang murah dan tentunya menginginkan orang lain terpusat pada dirinya, (2) gaya hidup mandiri yaitu memahami kelebihan dan kekurangan pada diri sendiri dan dapat mandiri (Chaney, 2011). Individu yang menganut gaya hidup hedonis selalu menomorsatukan kesenangan dan kenikmatan sebagai tujuan yang wajib didapatkan dalam kehidupan mereka, tidak mau membeli barang-barang yang murah dan selalu menginginkan barang yang kualitas nomor satu (branded). Tujuan membeli barang branded yaitu untuk mendapatkan kesenangan dan kenikmatan tersendiri dalam hidupnya sehingga cenderung boros dan menjadi pusat perhatian merupakan harapan bagi individu tersebut.

Gaya hidup hedonis biasanya terjadi pada orang yang berdomisili di kota karena dimanjakan dengan segala fasilitas yang ada, seperti mall, restoran, kafe, apartemen, hotel, dan fasilitas lainnya yang tentunya jaraknya tidak jauh dari rumah sehingga sangat mudah untuk dijangkau semua kalangan, khususnya siswa SMA. Sekolah terletak di perkotaan dan dekat dengan shopping center dapat memicu timbulnya perilaku gaya hidup hedonis. Fenomena banyaknya siswa SMA yang suka bermain ke mall, baik itu sekedar jalan-jalan, belanja dengan teman-temannya, atau hanya sekedar ingin makan bersama di mall. Ada pula siswa yang senang bermain dengan teman-temannya dan menghabiskan waktu untuk hangout di kafe. Dapat disimpulkan bahwa siswa SMA tersebut sudah mulai bergaya hidup hedonis, karena individu senang menghabiskan waktunya di luar rumah tujuannya untuk mencari kesenangan dengan teman-temannya. Gaya hidup mencerminkan setiap orang dalam berinteraksi dengan lingkungan sekitarnya dan semua itu tidak bisa lepas dari pengaruh orang-orang dan keadaan yang ada di sekitarnya (Kotler \& Amstrong, 2008). 
Aspek gaya hidup hedonis terdiri atas (1) kegiatan (activities), yaitu lebih banyak melakukan kegiatan di luar rumah, cenderung sering membeli barang bukan karena kebutuhan, sering mengunjungi pusat perbelanjaan serta menghabiskan waktu untuk pergi ke kafe, (2) minat (interest), dalam hal memenuhi kebutuhan fashion, makanan, barang-barang branded (mewah), tempat yang disenangi untuk sekedar berkumpul dengan teman, dan cenderung ingin menjadi pusat perhatian dari orang-orang di sekitarnya dan (3) opini (opinion), jawaban atas pertanyaan yang merupakan sebuah pemikiran, harapan, dan evaluasi dalam perilaku yang muncul (Trimartati, 2014).

Gaya hidup seseorang dapat berubah ketika seseorang mulai beranjak remaja. Biasanya seseorang yang mulai beranjak ke masa remaja, sudah mulai dapat menetapkan gaya hidupnya. Hal tersebut dipengaruhi oleh keluarga, lingkungan tempat tinggal, dan lingkungan bermain (Schiffman \& Kanuk, 2004). Masa remaja cepat terpengaruh sesuatu yang baru, karena memiliki rasa penasaran yang tinggi. Seorang remaja lebih cenderung melakukan segala aktivitasnya dengan cara berkelompok, mereka membutuhkan penerimaan diri dari anggota kelompoknya, dan tentunya ingin menjadi pusat perhatian disetiap kelompoknya, oleh karena itu remaja lebih cenderung menganut gaya hidup hedonis (Kusumanugraha dalam Zulkifli, 2016).

Gaya hidup hedonis juga dipengaruhi oleh media elektronik salah satunya smart phone. Setiap remaja pada masa kini mempunyai smart phone yang dapat mengakses berbagai macam informasi dari sosial media. Informasi yang menampilkan berbagai gaya hidup dari dalam negeri maupun luar negeri dapat diakses dengan mudah. Hal tersebut dapat memicu perilaku gaya hidup hedonis siswa SMA dengan sering membicarakan berbagai macam fashion dan gaya berpakaian saat jam pelajaran berlangsung. Serupa dengan pendapat Yanti (2016) yang menyatakan bahwa peran media sosial sangat berpengaruh terhadap masyarakat untuk mencoba gaya hidup hedonis. Banyak dari kalangan artis, pejabat, dan politisi yang justru lebih bergaya hidup glamor, dan gaya hidup mereka selalu diunggah melalui media sosial, dan secara tidak langsung masyarakat cenderung menirukan gaya hidup hedonis tersebut.

Akibat yang ditimbulkan dari gaya hidup hedonis yang dilakukan oleh remaja SMA yaitu dapat menghambat kegiatan belajarnya. Siswa yang menganut gaya hidup hedonis terkadang menomorduakan pendidikan. Permasalahan siswa yang menganut gaya hidup hedonis ini tentunya berdampak buruk dalam kehidupan dimasa depan, dan prestasi akademik menjadi menurun. Peran konselor dalam memberikan layanan dan pemahaman kepada siswa sangatlah penting, agar terhindar dari gaya hidup hedonis yang akan merugikan dirinya sendiri. Konselor bisa memberikan layanan kepada siswa yang menganut gaya hidup hedonis menggunakan teknik self-management, karena merupakan salah satu teknik kognitif behavioral berdasar pada teori belajar yang didesain untuk membangun siswa mengontrol dan mengubah perilakunya kearah yang lebih efektif, dapat dikombinasikan dengan self reward. Perilaku manusia cenderung memiliki sisi baik dan buruk. Tingkah laku individu diperoleh dari pengalaman (proses belajar) dengan merespons rangsangan yang ada di lingkungannya (Alamri, 2015; Mappiare, 2006).

Self-management merupakan proses pengubahan perilaku konseli menggunakan self monitoring, stimulus control, dan self reward tanpa adanya paksaan dari orang lain (Komalasari, dkk., 2014; Cormier \& Cormier dalam Marwi \& Sutijoyo, 2012). Pemberian konseling dengan teknik ini, siswa diberikan kesempatan untuk memantau dan mengatur perilakunya sendiri. Melalui strategi dan tahapan self-management, siswa sendiri yang dapat mengubah perilakunya menjadi lebih baik. Tujuannya untuk meningkatkan kontrol diri berdasarkan dari teori pembelajaran sosial dari Bandura.

Kelebihan dari teknik self-management yaitu individu yang melakukan perubahan mampu mengendalikan masalah dan mampu melakukan perubahan sendiri. Individu melakukan perubahan sesuai dengan keinginan dan kemauan yang datang dari dirinya sendiri, proses perubahan tersebut akan bertahan lama dan dapat diterima oleh dirinya sendiri. Serupa dengan pendapat Newman \& Eyck (2005) menyatakan bahwa teknik self-management mempunyai keunggulan yaitu siswa mampu bertanggung jawab dalam memantau dan memperkuat tingkah lakunya sendiri. Dampak yang diharapkan dari pemberian konseling teknik self-management yaitu gaya hidup hedonis siswa dapat tereduksi sehingga siswa dapat mengontrol diri dari perilaku yang memicu timbulnya gaya hidup hedonis.

\section{METODE}

Penelitian kuantitatif rancangan eksperimen semu (quasi experiment) dengan nonequivalent control group design dilaksanakan kelompok eksperimen dan kelompok kontrol. Rancangan penelitian yang digunakan menggunakan subjek yang sudah ada dalam kelompok-kelompok yang telah ditentukan sebelum adanya penelitian. Subjek yang dilibatkan yaitu siswa kelas XI IPS 1 dan IPS 2 SMAN 8 Malang yang sebelumnya tidak diacak, ditambah atau dikurangi jumlah siswa pada kelas tersebut. Kelompok eksperimen diberikan tes awal (pretest), selanjutnya diberikan perlakuan berupa implementasi konseling kelompok dengan teknik self-management untuk mereduksi gaya hidup hedonis selama tujuh pertemuan setelah itu diberikan tes akhir (posttest) untuk mengetahui perbedaan skor sebelum dan sesudah diberikan perlakuan. Kelompok kontrol diberikan tes awal (pretest), selanjutnya diberikan perlakuan berupa implementasi konseling kelompok dengan teknik modeling selama tujuh pertemuan kemudian diberikan tes akhir (posttest). Subjek diberikan skala gaya hidup hedonis sebagai posttest setelah selesai diberikan perlakuan. Skala gaya hidup hedonis yang digunakan untuk posttest sama dengan skala pretest. Hal tersebut dilaksanakan untuk mengetahui perbedaan skor pada kelompok eksperimen dan kelompok kontrol setelah diberikan perlakuan. 


\section{Subjek Penelitian}

Subjek yang digunakan yaitu siswa kelas XI IPS 1 dan XI IPS 2 SMAN 8 Malang pada tahun ajaran 2018/2019. Skala gaya hidup hedonis untuk menjaring subjek pada kelas tersebut. Kelas XI IPS 1 SMAN 8 Malang sebagai kelompok eksperimen dengan mengimplementasikan konseling kelompok teknik self-management. Subjek sebagai kelas kontrol atau kelompok pembanding yaitu kelas XI IPS 2 SMAN 8 Malang dengan diberikan perlakuan berupa implementasi konseling kelompok teknik modeling. Alasan memilih teknik modeling pada kelompok kontrol yaitu sebagai pembanding dari kelompok eksperimen yang menggunakan teknik self-management.

Penelitian ini menggunakan purposive sampling untuk mengambil subjek yang akan diberikan intervensi. Teknik sampling ini adalah salah satu cara menentukan sampel penelitian menggunakan kriteria yang telah ditentukan oleh peneliti (Sugiyono, 2015). Dari jumlah siswa, subjek penelitian yang diberikan perlakuan terdiri dari 12 sampel yang terindikasi gaya hidup hedonis. Sebanyak enam siswa dari kelas XI IPS 1 merupakan kelompok eksperimen yang kemudian diberi perlakuan menggunakan konseling kelompok teknik self-management dan enam siswa kelas XI IPS 2 sebagai kelompok kontrol yang akan diberikan perlakuan menggunakan konseling kelompok teknik modeling. Berdasarkan kriteria yang telah dipaparkan, diperoleh subjek penelitian sebagai berikut.

Tabel 1. Subjek Penelitian

\begin{tabular}{lccc}
\hline & $\begin{array}{c}\text { XI IPS 1 } \\
\text { (Kelompok Eksperimen) }\end{array}$ & $\begin{array}{c}\text { XI IPS 2 } \\
\text { (Kelompok Kontrol) }\end{array}$ & Total \\
\hline $\begin{array}{l}\text { Jumlah siswa } \\
\text { Subjek yang terindikasi gaya hidup hedonis tinggi } \\
\text { Perlakuan }\end{array}$ & 33 siswa & 6 siswa siswa & 64 siswa \\
& $\begin{array}{c}\text { Diberikan perlakuan teknik } \\
\text { Self-management }\end{array}$ & $\begin{array}{c}\text { Diberikan perlakuan } \\
\text { teknik modeling }\end{array}$ & 12 siswa \\
\hline
\end{tabular}

\section{Instrumen Pengumpulan Data}

Peneliti menggunakan skala gaya hidup hedonis, tujuannya yaitu untuk melihat kondisi responden yang memiliki gaya hidup hedonis. Penyusunan skala berdasarkan kisi-kisi sehingga dapat menghasilkan item pernyataan dan kemungkinan jawabannya. Instrumen ini menggunakan empat alternatif jawaban dari model skala Likert yang dimodifikasi. Skala sikap dengan kriteria empat alternatif pernyataan favorable dan unfavorable, yaitu sangat sesuai (ST), sesuai (S), kurang sesuai (KS), dan tidak sesuai (TS).

Skala gaya hidup hedonis terdiri atas 56 butir pernyataan yang telah diuji validitas ahli dengan koefisien validitas Aiken's V. Uji validitas ahli diperoleh butir dengan kriteria validitas sangat tinggi sebanyak 51 butir, kriteria validitas tinggi sebanyak empat butir dan kriteria validitas sedang sebanyak satu butir. Skala gaya hidup hedonis dilakukan uji empirik dengan melakukan try out kepada siswa di dalam populasi namun di luar sampel. Siswa yang digunakan untuk try out yaitu kelas XI IPS 3 dengan banyak 33 siswa. Hasil try out diuji mengunakan rumus koefisien korelasi product moment yang diperoleh $\mathrm{r}_{\mathrm{tabel}}$ sebesar 0,344 sehingga dari 56 butir sebanyak tujuh butir pernyataan yang tidak valid dan 49 butir dinyatakan valid. Dengan demikian, skala gaya hidup hedonis yang telah valid dilakukan uji reliabilitas untuk mendapatkan keabsahan data. penelitian. Uji reliabilitas menggunakan koefisien Cronbach's Alpha dengan diperoleh nilai sebesar 0,954 > 0,6 dan dinyatakan skala gaya hidup hedonis reliabel dan dapat digunakan untuk penelitian. Suatu instrumen dikatakan reliabel apabila nilai Cronbach's Alpha > 0,6 (Sarjono \& Julianita, 2013). Skala gaya hidup hedonis juga digunakan untuk menentukan subjek yang akan diberikan perlakuan. Berikut merupakan kategori gaya hidup hedonis.

Tabel 2. Kategori Gaya Hidup Hedonis

\begin{tabular}{cc}
\hline Skor & Kategori \\
\hline $49-85$ & Rendah \\
\hline $86-122$ & Sedang \\
\hline $123-159$ & Tinggi \\
\hline $160-196$ & Sangat Tinggi \\
\hline
\end{tabular}

Instrumen pengumpulan data yang kedua yaitu pedoman observasi yang digunakan untuk mengamati perilaku-perilaku siswa yang menganut gaya hidup hedonis. Semua perilaku yang muncul diobservasi, sehingga dapat mengetahui perubahan perilaku yang muncul ketika dilakukan pemberian perlakuan. Instrumen pengumpulan data ketiga yaitu pedoman wawancara yang dikembangkan peneliti untuk memperoleh informasi mengenai gaya hidup hedonis. Wawancara dilakukan peneliti kepada konselor sekolah dan siswa. 


\section{Panduan Konseling Kelompok Teknik Self-Management}

Panduan ini bertujuan sebagai pedoman melaksanakan penelitian. Sebelum panduan diimplementasikan, terlebih dahulu diuji validasi ahli. Panduan yang diterapkan pada kelompok kontrol juga telah divalidasi agar kedua panduan tersebut layak digunakan untuk penelitian. Panduan penelitian divalidasi oleh dua dosen ahli. Analisis uji ahli panduan konseling menggunakan model kesepakatan inter-rater agreement model (Gregory, 2011) sebagaimana ditunjukkan pada tabel 3.

Tabel 3. Inter-Rater Agreement Model

\begin{tabular}{|c|c|c|c|}
\cline { 3 - 3 } \multicolumn{2}{c|}{} & \multicolumn{2}{c|}{ Pendapat Ahli 1 } \\
\cline { 3 - 4 } \multicolumn{2}{c|}{ Pendapat Ahli 2 } & $\begin{array}{c}\text { Relevansi Rendah } \\
\text { (Skor 1-2) }\end{array}$ & $\begin{array}{c}\text { Relevansi Tinggi } \\
\text { (skor 3-4) }\end{array}$ \\
\hline $\begin{array}{c}\text { (Skor 1-2) } \\
\text { Relevansi Tinggi } \\
\text { ( skor 3-4) }\end{array}$ & A & B \\
\hline
\end{tabular}

Hasil dari penilaian ahli pertama dan kedua terhadap panduan teknik self-management dan teknik modeling diperoleh indeks sebesar satu dengan kriteria validitas sangat tinggi sehingga panduan tersebut layak untuk digunakan sebagai bahan perlakuan dalam penelitian.

\section{Prosedur Penelitian}

Prosedur penelitian meliputi tahap persiapan, peralihan, kegiatan dan pengakhiran. Prosedur penelitian digunakan sebagai acuan dalam menyelesaikan penelitian. Kegiatan konseling pada kelompok eksperimen dan kelompok kontrol dilaksanakan dalam tujuh pertemuan.

\section{Analisis Data}

Data dianalisis menggunakan statistic non-parametric dengan rumus Wilcoxon untuk menguji hipotesis dari sampel yang berpasangan dan mengetahui perbedaan skor pretest dan posttest. Hipotesis dinyatakan diterima apabila nilai Asymp.Sig < 0,05, maka ada perbedaan skor pretest dengan posttest. Hipotesis ditolak jika nilai Asymp.Sig $>0,05$ maka tidak ada perbedaan antara skor pretest dengan posttest.

Mann Whitney U Test digunakan untuk menguji hipotesis komparatif dua sampel independen yang memiliki data berbentuk ordinal dan untuk mengetahui perbedaan skor dari kedua kelompok setelah diberikan perlakuan. Hipotesis dinyatakan diterima apabila nilai Asymp.Sig (1-tailed) yang diperoleh < 0,05, maka ada perbedaan keefektifan antara kelompok eksperimen dan kelompok kontrol. Sebaliknya hipotesis ditolak jika nilai Asymp.Sig > 0,05 maka tidak ada perbedaan keefektifan antara kelompok eksperimen dan kelompok kontrol.

\section{HASIL}

Data kuantitatif diperoleh dari skor pretest dan posttest dari setiap kelompok. Sedangkan data kualitatif dihasilkan dari observasi, wawancara dan tugas-tugas siswa selama proses konseling. Pemberian pretest sebagai penjaringan subjek akan digunakan untuk melakukan kegiatan konseling. Penjaringan subjek diperoleh enam siswa kelas XI IPS 1 sebagai kelompok eksperimen (self-management) dan enam siswa kelas XI IPS 2 untuk kelompok kontrol (modeling). Kemudian diberikan posttest untuk mengetahui perbedaan skor sebelum dan sesudah diberikan perlakuan. Berikut hasil dari kelompok eksperimen. 


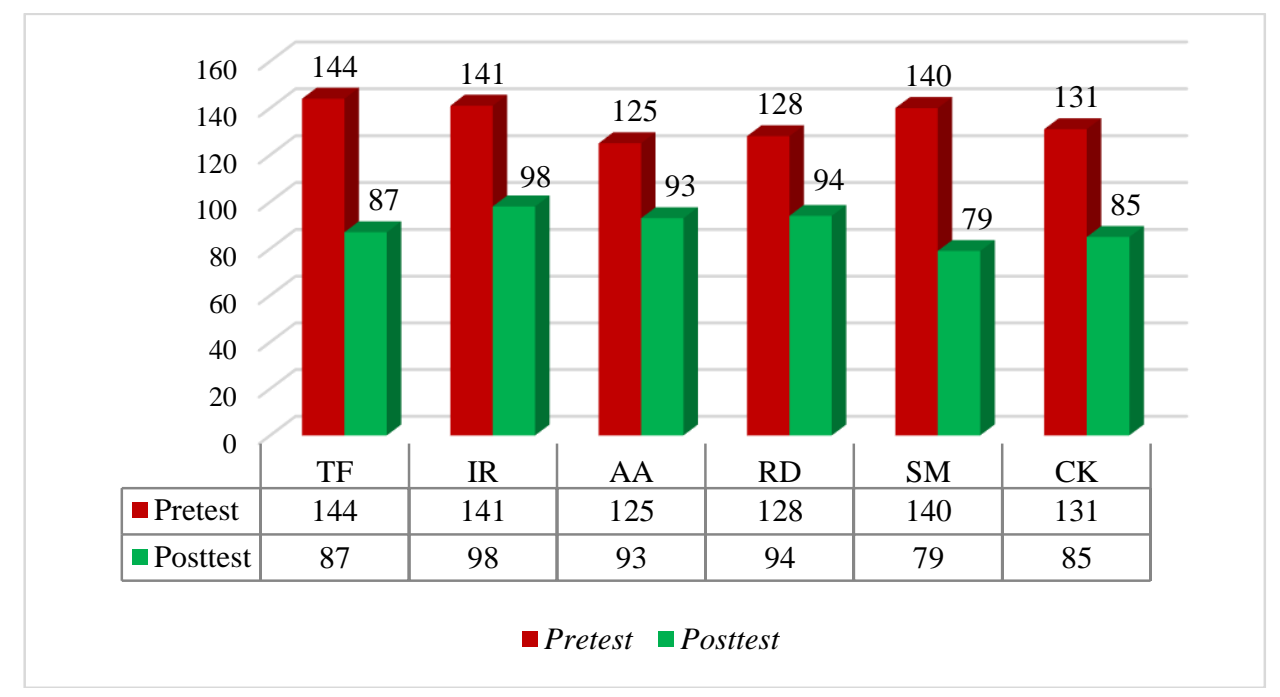

\section{Gambar 1. Skor Pretest dan Posttest Skala Gaya Hidup Hedonis Kelompok Eksperimen}

Berdasarkan gambar 1, kelompok eksperimen di atas, dilakukan uji hipotesis menggunakan statistik non parametrik dengan rumus Wilcoxon. Hipotesis pertama pada penelitian ini yaitu teknik self-management efektif untuk mereduksi gaya hidup hedonis siswa SMAN 8 Malang. Hasil uji Wilcoxon pada kelompok eksperimen diperoleh enam siswa yang mengalami penurunan skor dan diperoleh Asymp.Sig (1-tailed) 0,014 < 0,05, maka $h_{o}$ ditolak dan $h_{a}$ diterima dan dapat disimpulkan bahwa teknik self-management efektif untuk mereduksi gaya hidup hedonis siswa SMAN 8 Malang. Hasil pada kelompok kontrol ditunjukkan sebagaimana ditunjukkan pada gambar 2.

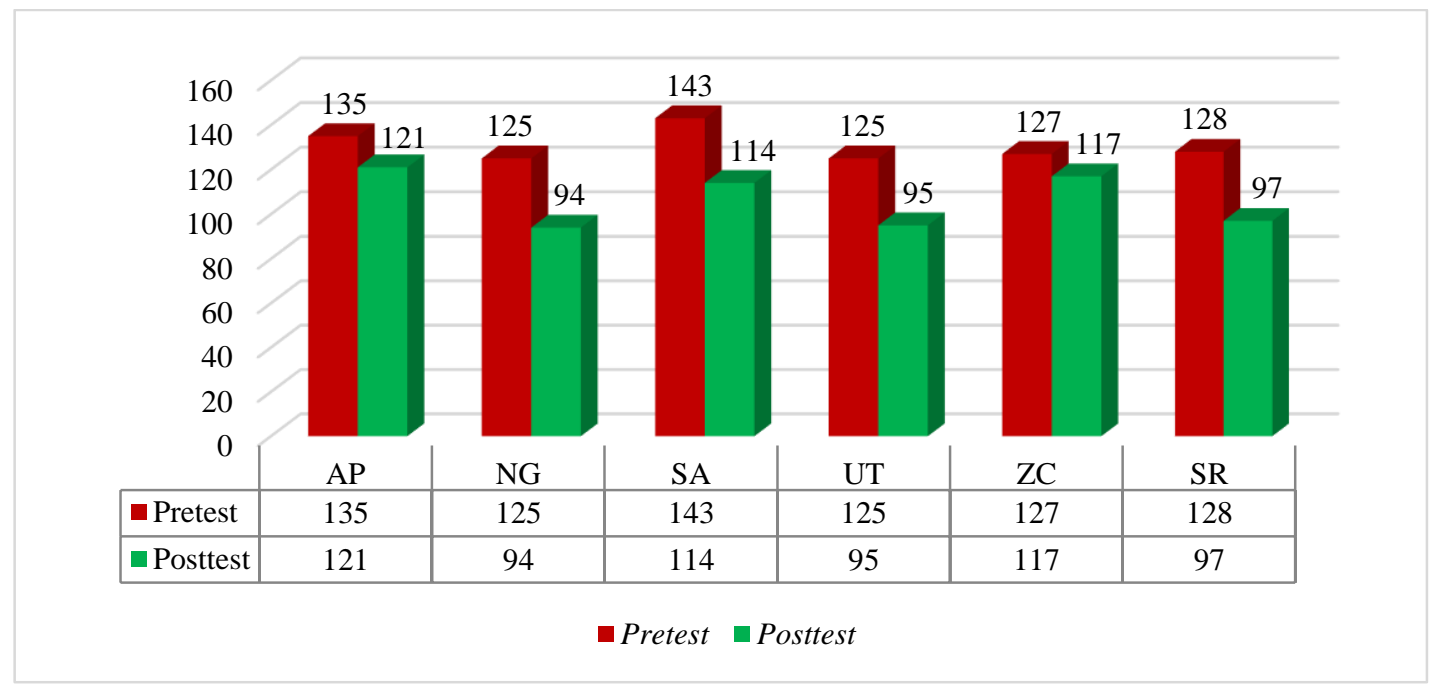

\section{Gambar 2. Skor Pretest dan Posttest Skala Gaya Hidup Hedonis Kelompok Kontrol}

Hipotesis kedua menyatakan bahwa teknik modeling efektif untuk mereduksi gaya hidup hedonis siswa SMAN 8 Malang. Berdasarkan hasil uji wilcoxon pada kelompok kontrol diperoleh enam siswa yang mengalami penurunan skor. Hasil dari uji Wilcoxon diperoleh nilai Asymp.Sig (1- tailed) 0,013<0,05, maka $h_{o}$ ditolak dan $h_{a}$ diterima dan kesimpulannya teknik modeling efektif untuk mereduksi gaya hidup hedonis siswa SMAN 8 Malang.

Hipotesis ketiga menyatakan bahwa teknik self-management lebih efektif daripada teknik modeling untuk mereduksi gaya hidup hedonis siswa SMAN 8 Malang. Uji hipotesis menggunakan Mann Whitney U Test terhadap hasil posttest kelompok eksperimen dan kontrol diperoleh nilai Asymp.Sig (1-tailed) 0,015 < 0,05, maka Ho ditolak dan Ha diterima. Hasil uji hipotesis menggunakan Mann Whitney U Test disimpulkan bahwa teknik self-management lebih efektif daripada teknik modeling untuk mereduksi gaya hidup hedonis siswa SMA N 8 Malang. 
Tabel 3. Deskripsi Data Posttest Kelompok Eksperimen

\begin{tabular}{cccccc}
\hline & N & Skor Minimum & Skor Maksimum & Mean & Std. Deviasi \\
\hline Posttest & 6 & 79 & 98 & 89,33 & 6,947 \\
Valid N (listwise) & 6 & 79 & & & \\
\hline
\end{tabular}

Tabel 4. Deskripsi Data Posttest Kelompok Kontrol

\begin{tabular}{cccccc}
\hline & N & Skor Minimum & Skor Maksimum & Mean & Std. Deviasi \\
\hline Posttest & 6 & 94 & 121 & 106,33 & 12,291 \\
Valid N (listwise) & 6 & & & & \\
\hline
\end{tabular}

Berdasarkan tabel deskripsi data posttest dari kelompok eksperimen dan kontrol diperoleh mean kelompok eksperimen sebesar 89,33 lebih kecil dari kontrol yang diperoleh sebesar 106,33 yang berarti mean skor gaya hidup hedonis pada kelompok eksperimen lebih rendah dibanding kelompok kontrol. Rata-rata gain skor (penurunan skor) kelompok eksperimen sebesar 273 lebih tinggi daripada kelompok kontrol sebesar 145. Kesimpulannya, teknik self-management lebih efektif daripada teknik modeling untuk mereduksi gaya hidup hedonis siswa SMAN 8 Malang.

\section{PEMBAHASAN}

Penelitian menggunakan teknik self-management terbukti efektif dapat menurunkan gaya hidup hedonis Siswa. Sejalan dengan Sa'diyah (2016) menyatakan teknik self-management efektif untuk mereduksi agresifitas remaja. Menurut peneliti adanya perubahan diri masa SMP menuju masa SMA, remaja mulai dewasa dan memiliki banyak teman, sering mengakses sosial media, pergaulan lebih luas, kebebasan yang diberikan orang tua, dan mulai mengikuti gaya hidup hedonis. Hal-hal yang dilihat secara langsung maupun melalui sosial media dapat memicu pikiran dan perilaku siswa untuk mengikuti gaya hidup tersebut. Peneliti menggunakan teknik self-management untuk mereduksi gaya hidup hedonis dikarenakan menurut teori, selfmanagement dapat mengubah perilaku ke arah yang lebih baik. Hal tersebut dikemukakan oleh beberapa ahli yang menyatakan self-management adalah salah satu teknik kognitif behavioral yang berdasar pada teori belajar yang dirancang untuk membangun siswa dalam mengontrol dan mengubah perilakunya (Alamri, 2015; Mappiare, 2006).

Gaya hidup hedonis dilatarbelakangi oleh faktor lingkukan remaja, globalisasi, kemajuan IPTEK yang tidak terfilter dengan baik oleh siswa. Hal negatif dari perkembangan zaman diterapkan oleh siswa secara terus menerus akan menjadi kebiasan buruk, salah satunya yaitu menganut gaya hidup hedonis. Apabila gaya hidup hedonis tidak direduksi, maka dapat berperilaku negatif dan dapat menghambat berbagai macam kegiatan positif yang seharusnya dilakukan. Selain itu, dapat merugikan diri sendiri dan orang lain. Hal tersebut serupa dengan pendapat Veenhoven (2003) yang menyatakan mengejar kesenangan membuat seseorang menghindari tantangan dan membuat seseorang tersebut menjadi tidak terlatih.

Remaja yang memiliki keinginan menyesuaikan diri dengan kelompok, ingin terlihat keren dan fashionable dari teman-temannya sehingga membuat siswa tersebut semakin bergaya hidup hedonis. Oleh sebab itu, harus direduksi menggunakan intervensi yang tepat. Cara untuk memodifikasi perilaku yaitu dengan menggunakan self-management (Moore, dkk., 2007). Ketika gaya hidup hedonis dapat direduksi, siswa tersebut diharapkan mampu untuk berperilaku secara positif pada masa perkembangan selanjutnya dan siswa mampu menerapkan teknik tersebut dalam kehidupannya, meskipun proses intervensi yang diberikan peneliti sudah berakhir.

Berdasarkan analisis data yang telah dilakukan, teknik self-management lebih efektif daripada teknik modeling untuk mereduksi gaya hidup hedonis siswa SMA N 8 Malang. Faktor yang mendukung keberhasilan teknik self-management yaitu dipengaruhi oleh motivasi dalam diri sendiri, dinamika kelompok selama proses konseling, adanya tugas rumah yang harus dikerjakan sesuai dengan keadaan dan kesadaran diri serta kerjasama antara anggota kelompok dengan konselor yang berjalan dengan baik.

Self-management ialah teknik yang menggunakan cognitive behavioral therapy. Menurut teori Bandura (dalam Anctil \& Degeneffe, 2003) yang menyatakan bahwa cognitive behavioral therapy merupakan gabungan antara strategi perilaku dan kognitif yang didasarkan pada proses untuk menghasilkan perubahan melalui proses kognitif. Pada proses pemberian intervensi, siswa mulai membangun dirinya sendiri dengan belajar dari pemikiran dan perilakunya sendiri. Kebiasaan gaya hidup hedonis dapat tereduksi dengan perubahan pemikiran dan perilaku dari dalam diri siswa yang dilakukan secara konsisten.

Teknik self-management berhasil menurunkan gaya hidup hedonis dikarenakan tujuan dari teknik ini yaitu mengajarkan siswa untuk memanajemen dirinya sendiri. Sehingga mereka dapat memikirkan kembali ketika akan melakukan perilaku yang memicu gaya hidup hedonis. Dengan teknik self-management, konselor mengajarkan siswa mengidentifikasi setiap pemikiran dan perilaku untuk diterapkan secara perlahan, bertahap dan terus menerus agar siswa dapat terbiasa mengontrol diri. Karena suatu hal yang dilakukan secara terus menerus akan menjadi kebiasaan bagi siswa tersebut. Hal tersebut sesuai dengan pendapat Barlow, dkk. (2002) yang menyatakan bahwa self-management mengacu pada kemampuan individu dalam pengelolaan dirinya. 
Penurunan skor gaya hidup hedonis siswa menunjukkan keefektifan teknik self-management. Penurunan skor gaya hidup hedonis dapat membantu siswa menyadari dan menyikapi segala hal yang kurang bermanfaat untuk dilakukan. Masingmasing siswa mengalami penurunan gaya hidup hedonis yang berbeda-beda, dikarenakan ketekunan dan keterampilan yang dimiliki siswa dapat ditingkatkan untuk menyeleksi faktor lingkungan yang memicu gaya hidup hedonis. Diperlukan ketekunan dan inisiatif diri sendiri dalam mengubah atau mengembangkan diri, agar perubahan dapat bertahan lama (Cormier, dkk., 2009).

Teknik modeling telah dibuktikan dapat mereduksi gaya hidup hedonis siswa SMA N 8 Malang. Dikarenakan teknik tersebut sangat sederhana dan mudah diterapkan untuk mengubah pandangan siswa. Teknik modeling merupakan teknik konseling behavior untuk memperkuat perilaku dengan membiasakan perilaku baru dengan menirukan model (Hidayah, dkk., 2018). Pandangan siswa yang semula mencontoh gaya hidup hedonis dari sosial media dihentikan dengan melihat model yang dapat memotivasi dirinya untuk mencontoh hal positif yang dilakukan. Model yang digunakan dalam teknik modeling merupakan siswa SMA yang memiliki perilaku positif yang dapat mengubah pandangan siswa yang memiliki gaya hidup hedonis menjadi lebih baik.

Hal yang membedakan kedua teknik tersebut yaitu teknik self-management, konselor berperan sebagai pengamat dan keseluruhan tahap dilakukan sendiri oleh siswa, karena keberhasilan dari self-management dapat dilihat dari seberapa serius siswa dalam melakukan perubahan tersebut. Tanggung jawab diserahkan kepada siswa untuk mengubah atau meningkatkan perilaku positifnya merupakan hal yang paling tepat dalam teknik self-management. Karena siswa tersebutlah yang mengetahui dan bertanggung jawab atas perbuatannya dengan demikian siswa tersebutlah yang berperan penting untuk mengubah dirinya (Cormier, dkk., 2009).

Pada teknik modeling, konselor selalu mendampingi siswa untuk mengamati model sehingga konselor sangat berperan dalam proses konseling. Tujuan dari modeling adalah membantu siswa untuk dapat menerapkan keterampilan yang dicontohkan oleh fasilitator atau video sesuai dengan tujuan mereka (Ramli, dkk., 2018). Dari kedua teknik tersebut, yang tepat untuk mereduksi gaya hidup hedonis yaitu teknik self-management. Teknik ini terbukti efektif karena siswa merasakan secara langsung perubahan tingkah lakunya sendiri. Hal tersebut sejalan dengan pendapat Newman \& Eyck (2005) yang menyatakan bahwa self-management mempunyai keunggulan yaitu siswa mampu bertanggung jawab dalam memantau dan memperkuat tingkah lakunya sendiri.

\section{Implikasi Hasil Penelitian}

Berdasarkan hasil penelitian diperoleh bahwa teknik self-management efektif untuk mereduksi gaya hidup hedonis siswa SMA. Teknik ini dapat digunakan sebagai salah satu alternatif layanan konseling kelompok khususnya mengatasi permasalahan gaya hidup hedonis siswa. Hasil penelitian menunjukkan bahwa teknik self-management lebih efektif dibandingkan dengan teknik modeling untuk mereduksi gaya hidup hedonis siswa SMAN 8 Malang. Penelitian ini dapat diterapkan untuk mereduksi gaya hidup hedonis pada subjek di perguruan tinggi.

Teknik ini dapat digunakan untuk menangani masalah lainnya yang berkaitan dengan manajemen diri. Hal ini dikarenakan self-management bertujuan membantu siswa untuk dapat me-manage pikiran dan perilaku yang akan dilakukan, serta digunakan untuk meningkatkan maupun mereduksi perilaku yang akan diubah. Hasil penelitian Wahyuningsih (2014) menunjukkan bahwa teknik self-management efektif untuk meningkatkan kemandirian siswa SMP dalam belajar. Hasil penelitian milik Latifah (2019) menunjukkan bahwa teknik self-management efektif untuk mengurangi perilaku membolos pada siswa SMP.

Teknik self-management dapat dilaksanakan dalam suasana kelompok, agar siswa dapat dengan mudah mengungkapkan permasalah yang sedang dihadapi dan siswa dapat aktif dalam mengutarakan pendapatnya masing-masing. Hal tersebut dapat mengurangi rasa khawatir siswa yang mengalami kesulitan untuk mengungkapkan permasalahan secara individu. Dengan konseling kelompok siswa dapat mendengarkan dan mengungkapkan pendapat dari anggota lain sehingga dapat menambah wawasan. Hal tersebut serupa dengan pendapat Prayitno (2004) yang menyatakan, tujuan dari konseling kelompok yaitu untuk meningkatkan kemampuan bersosialisasi dan komunikasi antar anggota yang disertai dengan perkembangan aspek kognitif, afektif, dan psikomotorik sehingga dapat mendukung penerapan teknik self-management untuk mereduksi gaya hidup hedonis siswa SMAN 8 Malang.

\section{Keterbatasan Penelitian}

Penelitian ini memilik keterbatasan diantaranya yaitu, kesulitan dalam mengumpulkan siswa secara lengkap, siswa terkadang mengalami kesulitan dalam mengikuti tahapan teknik self-management sehingga konselor selalu mengingatkan materi yang dibahas pada pertemuan sebelumnya. Peneliti juga mengalami keterbatasan waktu pelaksanaan teknik konseling yang diberikan oleh pihak sekolah. 


\section{SIMPULAN}

Berdasarkan hasil dan kajian, dihasilkan tiga kesimpulan dari rumusan masalah. Simpulan yang pertama yaitu teknik self-management efektif untuk mereduksi gaya hidup hedonis siswa SMAN 8 Malang. Hal ini diketahui adanya penurunan skor gaya hidup hedonis yang didukung adanya perubahan pemikiran dan perilaku negatif siswa ke arah yang lebih positif terhadap kegiatan yang memicu gaya hidup hedonis.

Simpulan kedua yaitu teknik modeling efektif untuk mereduksi gaya hidup hedonis siswa SMAN 8 Malang. Hal tersebut didukung adanya kemampuan siswa dalam memahami perilaku model yang ditiru sehingga siswa dapat mereduksinya. Hal ini diketahui dari penurunan skor skala gaya hidup hedonis setelah diberikan intervensi menggunakan teknik modeling.

Simpulan ketiga yaitu teknik self-management lebih efektif untuk mereduksi gaya hedonis siswa SMAN 8 Malang. Hal tersebut diketahui dari selisih jumlah skor posttest kelompok eksperimen lebih tinggi dari kelompok kontrol. Keunggulan teknik self-management yang memiliki tahapan yang lengkap dan mendalam dari pada teknik modeling yang hanya mengamati suatu model. Siswa sangat berperan penuh dalam teknik self-management dibandingkan teknik modeling. Pada teknik selfmanagement konselor mengajarkan siswa mengidentifikasi setiap pemikiran dan perilaku untuk diterapkan secara perlahan, bertahap dan terus menerus agar siswa dapat mengontrol diri. Siswa juga mendapatkan tugas rumah sehinggga siswa dapat mengamati gaya hidup hedonis yang biasa dilakukan, kemudian siswa juga dapat melakukan pengontrolan agar gaya hidup hedonis menurun, ketika siswa berhasil melakukan pengontrolan tersebut siswa mendapatkan penghargaan.

Konselor membimbing siswa untuk me-manage diri sendiri melakukan pengontrolan saat menghadapi situasi yang memicu gaya hidup hedonis. Penurunan skor tersebut dapat dimaknai bahwa teknik self-management memberikan dampak positif bagi siswa sebagai strategi untuk mereduksi gaya hidup hedonis. Teknik self-management telah dibuktikan efektif untuk mengurangi dan meningkatkan perilaku yang diinginkan. Teknik self-management telah digunakan oleh beberapa peneliti terdahulu. Keunggulannya yaitu siswa merasakan secara langsung perubahan tingkah lakunya dan siswa mampu bertanggung jawab dalam memantau dan memperkuat tingkah lakunya sendiri.

\section{Saran untuk Konselor Sekolah}

Konselor di sekolah perlu memperhatikan ketika siswa mulai terindikasi gaya hidup hedonis sehingga siswa tersebut langsung bisa diberikan intervensi agar tidak memiliki gaya hidup hedonis yang tinggi. Serta mengajarkan kepada siswa untuk hidup sewajarnya dan menyadarkan siswa bahwa kebahagiaan hidup tidak diukur dari materi. Saran untuk konselor di sekolah yaitu dapat menerapkan intervensi teknik self-management sebagai alternatif teknik untuk mereduksi gaya hidup hedonis.

\section{Saran untuk Peneliti Selanjutnya}

Perlu menambah durasi waktu dan jumlah pertemuan. Penerapan self-management digali lebih dalam dan dapat dikombinasikan dengan teknik lain dengan subjek yang berbeda. Teknik self-management juga dapat diterapkan untuk mereduksi gaya hidup hedonis pada subjek yang lebih luas serta dapat digunakan desain eksperimen yang lain.

\section{DAFTAR RUJUKAN}

Alamri, N. (2015). Layanan Bimbingan Kelompok dengan Teknik Self-Management untuk Mengurangi Perilaku Terlambat Masuk Sekolah (Studi pada Siswa Kelas X SMA 1 Gebog Tahun 2014/2015). Jurnal Konseling Gusjigang, 1(1). https://doi.org/10.24176/jkg.v1i1.259.

Anctil, T., \& Degeneffe, C. E. 2003. Self-Management and Social Skills Training for Persons with Developmental Disabilities: Tools for The Rahabilitation Counselor to Facilitate Success in Community Settings: A Literature Review. Journal of Applied Rehabilitation Counseling, 34(1), 17-24.

Barlow, J., Wright, C., Sheasby, J., Turner, A., \& Hainsworth, J. (2002). Self-Management Approaches for People with Chronic Conditions: A Review. Patient Education and Counseling, 48(2), 177-187. https://doi.org/10.1016/S07383991(02)00032-0.

Cormier, S., Nurius, P. S., \& Osborn, C. J. (2009). Interviewing and Change Strategies Fundamental Skills and Cognitive Behavioral Interventions.

Hidayah, N., Ramli, M., \& Hanafi, H. 2018. Modeling Technique on Madurese Culture Based on Bhupa' Bhabu' Ghuru Rato' Values. Advences in Social Science, Education and Humanities Research, 285,International Conference on Education and Technology (ICET 2018), published by Atlantis Press, 2352-5398.

Komalasari, G., Eka, W., \& Karsih. (2014). Teori dan Teknik Konseling. Jakarta: PT Indeks.

Kotler, P. \& Amstrong, G. (2008). Prinsip-Prinsip Pemasaran. Jakarta: Erlangga.

Latifah, L. (2019). Effectivenessof Self-Management Techniques to Reduce Truant Students Behavior in Middle School. Konselor, 8 (1), 17-22. https://doi.org/10.24036/0201981103804-0-00

Mappiare, A. (2006). Kamus Istilah Konseling dan Terapi. Jakarta: PT. Raja Grafindo Persada.

Marwi, T. I., \& Sutijono. (2012). Penggunaan Strategi Pengelolaan Diri (Self-Management) untuk Mengurangi Tingkat Kemalasan Belajar pada Siswa Kelas VIII E MTs AL Rosyid Dander-Bojonegoro. Jurnal Psikologi Pendidikan dan Bimbingan, 13(1). 
Moore, S. G., Dupaul, G. J., \& White, G. P. (2007). Self-Management of Classroom Preparedness and Homework: Effects on School Functioning of Adolescents with Attention Deficit Hyperactivity Disorder. School Psychology Review, 36(4), 647-664.

Newman, B. (2005). Self-Management of Initiations by Students Diagnosed with Autism. The Analysis of Verbal Behavior, 21, $117-122$.

Prayitno. (2004). Layanan Bimbingan Kelompok dan Konseling Kelompok. Padang: Universitas Negeri Padang.

Ramli, M., Hidayah, N. Fauzan, L. (2018). Effectiveness of Structured Learning Approach to Improve Counselor Competence in Applying Solutions-Focused Counseling. Advances in Social Science Education and Humanities Research, 285, International Conference on Education and Technology (ICET 2018), published by Atlantis Press.

Sa'diyah, H. (2016). Penerapan Teknik Self-Management untuk Mereduksi Agresivitas Remaja. Jurnal Ilmiah Counsellia, 6 (2), 67-78.

Safitri, A. (2012). Pengaruh Budaya Hedonis terhadap Timbulnya Vandalisme Siswa SMK Tri Dharma 3 dan SMK YKTB 2 Kota Bogor, 2(2), 96-122.

Sarjono, H., \& Julianita, W. (2013). SPSS VS LISREL Sebuah Pengantar Aplikasi untuk Riset. Jakarta: Salemba Empat.

Schiffman, L. G., \& Kanuk, L. (2004). Consumer Behavior (Eight Edition). New Jersey: Pearson Practice Hall.

Sugiyono. (2015). Statistika untuk Penelitian. Bandung: Alfabeta.

Trimartati, N. (2016). Studi Kasus tentang Gaya Hidup Hedonisme Mahasiswa Bimbingan dan Konseling Angkatan 2011 Universitas Ahmad Dahlan. Psikopedagogia: Jurnal Bimbingan dan Konseling, 3(1), 20. https://doi.org/10.12928/psikopedagogia.v3i1.4462.

Veenhoven, R. 2003. Hedonism and Happiness. Journal of Happiness Studies, 4, 437-457, https://link.springer.com/article/10.1023/B:JOHS.0000005719.56211.fd.

Wahyuningsih, D. 2014. Efektivitas Teknik Self-Management untuk Meningkatkan Kemandirian Belajar Siswa SMP. Tesis tidak diterbitkan. Universitas Negeri Malang, Malang.

Yanti, F. (2016). Dinamika Kecenderungan Gaya Hidup Hedonis dan Perilaku Seks Bebas pada Remaja Putri. Jurnal Ilmiah Mahasiswa Bimbingan \& Konseling, 1(1), 40-47.

Zulkifli, A. R. (2016). Gaya Hidup Hedonisme di Kalangan Mahasiswa Fakultas Ilmu Sosial dan Ilmu Politik Universitas Mulawarman. Jurnal Sosiatri-Sosiologi, 4(1), 72-85. 